\title{
Freemium business models as the foundation for growing an e-business venture: a multiple case study of industry leaders
}

\author{
Franziska Günzel-Jensen ${ }^{1}$, Anna B. Holm²
}

\begin{abstract}
In e-business freemium business models have become legitimate. However, current research provides little insight on how the free and premium offering should be employed to lead to growth and success in the long run. The presented research aims to fill this gap by investigating how the property 'free' was employed in young entrepreneurial ventures' business models in the initial life-cycle stages - opportunity recognition, market entry, and market exploitation. We find that various forms of freemium business models are employed through the initial life-cycle stages of a new venture for reasons of trial-and-error, learning, exploration, legitimization and resource acquisition. A freemium business model can also serve as a nascent business model, though without a sustainable monetization component, for finding a sustainable business model through a series of dynamic adjustments. With our findings we contribute to the business model literature in three ways: First, our empirical findings show the many-sidedness of the component 'free' in freemium business models. Free users are of importance for network building, exploration and exploitation and growth over time. Moreover, free users enable directly and indirectly further resource acquisition. Second, while previous literature has taken a static perspective, we contribute by illustrating the dynamic process of strategic business model design for growth. Finally, we introduce the concept of the nascent business model which is new to the literature.

Keywords: business model, case study, entrepreneurial venture, freemium, growth, IT, nascent business model.

\section{INTRODUCTION}

New businesses often start either from a market vision or from a technological capability. In both cases, the initial idea must be exploited with the aid of a

1 Assistant Professor, Aarhus University, Department of Management, Bartholins Allé 10, 8000 Aarhus C, Denmark, e-mail: frang@badm.au.dk.

2 Associate Professor, Aarhus University, Department of Management, Bartholins Allé 10, 8000 Aarhus C, Denmark, e-mail: annah@badm.au.dk.
\end{abstract}


business model (Chesbrough \& Rosenbloom, 2002) through value creation and capture activities (Teece, 2010; Zott, Amit, \& Massa, 2011). However, practice often shows that not every business model is designed and employed for the purpose of exploitation and growth from the beginning (Massa \& Tucci, 2013). The example of Google illustrates this perfectly. The firm started merely with a new technology for Internet search that was free and proved wildly successful with users due to its extraordinary utility, but with no idea whatsoever of how to make money from that. This was solved after some time when the firm invented yet another clever technology for selling space to advertisers on the users' search result web pages. The advertisers became Google's paying customers and the main source of revenues, and Google users enjoying the free service turned out to be a part of Google's value proposition (Kesting \& Günzel-Jensen, 2015). This realization led eventually to a successful business model, which was not envisioned from the beginning (Baden-Fuller \& Haefliger, 2013). After more than 15 years of existence, Google has become one of the most influential, profitable, and fastest growing companies in the world (Google Inc., 2013).

As in the case of Google, the logic of 'free' implies that ventures offer (parts of) their products or services for a price equalling zero, earning money elsewhere. Some authors claim that zero is the only reasonable price in the digital world (e.g. Andersen, 2009), while others point out that various young entrepreneurial companies have failed to convert 'free' into a sustainable business (Teece, 2010). Freemium has become one of the most prominent ways to earn money - giving a majority of users access to a basic version of the offering while charging few for a premium product or service (Teece, 2010). Some of the most commonly encountered freemium models are feature-limited and time-limited as well as hybrids hereof (Anderson, 2009). Although previous research has investigated various alternative revenue streams or more generic different patterns around freemium business models (McGrath, 2010; Osterwalder \& Pigneur, 2010), the value and implication of the free offering for the growth and profitability of young entrepreneurial ventures are largely unexplored although freemium business models are largely applied in the internet.

We approach the topic through the theoretical lens of the business model concept (Baden-Fuller \& Haefliger, 2013; Baden-Fuller \& Mangematin, 2013; Baden-Fuller \& Morgan, 2010) that can be referred to as a representation of the firm's realised strategy (Teece, 2010). Some research on business models consequently suggests that business models have properties that can translate into sustainable competitive advantage and superior financial performance (Amit \& Zott, 2001; Zott \& Amit, 2007) and that strategic business model design can influence high growth. Business models also 
change over time, with implications for company performance as well as growth potential (Teece, 2007; Voelpel, Leibold, \& Tekie, 2004). This research looks specifically at the property of 'free'in freemium business models and investigates how this has led to growth. More specifically, we investigate how young entrepreneurial ventures employed freemium business models (Osterwalder \& Pigneur, 2010) in the initial life-cycle stages - opportunity recognition, market entry, and market exploitation (George \& Bock, 2011). Following Bhide (2000) and Zott and Amit (2007) we define entrepreneurial firms as relatedly young organizations that have the potential of attaining significant size and profitability. For the purpose of this research, we conducted four case studies of successful e-business companies of this type.

The remainder of the paper is structured as follows: In the next section, we review business model and freemium literature and outline our research question. This leads to a description of our methodological approach, the data collection and analysis procedures. Following an account of the case studies, we then consider the relationship between the business model property 'free' and growth of an entrepreneurial venture. Finally, we suggest directions for further research and consider the implications of our study for entrepreneurs.

\section{Literature review}

Entrepreneurship researchers have pointed to growth as the crucial indicator for venture success and thus venture growth has become an important performance measure (Low \& MacMillan, 1988). Growth brings several advantages to an entrepreneurial firm: it increases its market power towards customers and suppliers, it expands its investment capacity in new products and technologies, and it raises the firm's visibility in markets to name only a few (ibid.). Therefore, growth is considered an important goal for new entrepreneurial ventures. High-growth firms are also of interest to other stakeholders because of their contribution to job creation and innovation (Achtenhagen, Naldi, \& Melin, 2010). A wide range of factors exists that affect the growth of firms ranging from the individual to organizational to environment level (Baum, Locke, \& Smith, 2001); however, the process of how various factors impact growth remains unexplored (Davidsson, Achtenhagen, \& Naldi, 2005; Leitch, Hill, \& Neergaard, 2010), and one of those poorly researched factors is the firm's business model.

\section{Business model}

In innovation management and strategy research the business model concept is often referred to as core business processes associated with value 
proposition, creation, delivery and capture (Günzel \& Holm, 2013; Holm, Günzel, \& Ulhøi, 2013; Johnson, Christensen, \& Kagermann, 2008; McGrath, 2010; Teece, 2010). Although business models have been integral to trading and economic behaviour since pre-classical times (Teece, 2010), the business model concept became prevalent with the advent of the Internet in the mid-1990s, and it has been gathering momentum since then (Zott et al., 2011). Recent advances in information and communication technologies have allowed the development of new ways to create, deliver and capture value, which have offered scope for the creation of unconventional exchange mechanisms and transaction architectures (Amit \& Zott, 2001) and accentuated the possibilities for the design of new boundary-spanning organizational forms (Daft \& Lewin, 1993; Dunbar \& Starbuck, 2006).

Indeed, these developments have opened new horizons for the design of business models by enabling firms fundamentally to change the way they organize and engage in economic exchanges, both within and across firm and industry boundaries (Mendelson, 2000). The freemium business model, where basic products or services are offered for a price of zero, has become an extremely popular model. The model became dominant primarily within Internet companies and companies that develop applications for smartphones. For example, 98\% of Google Play Store revenue and 95\% of Apple's app Store revenue come from freemium applications (Froberg, 2015).

The freemium business model for e-business is best described using the typology proposed by Baden-Fuller, Haefliger and Mangematin (Baden-Fuller \& Haefliger, 2013; Baden-Fuller \& Mangematin, 2013) based on the following four dimensions: 1) customer identification, 2) customer engagement, 3) value delivery, and 4) monetization. Following this typology, for freemium e-business models we can define the four dimensions as follows. First, the logic of freemium implies that a part of the product is free for almost everyone often attracting a large number of users who do not pay. In sustainable business models, payment is made by others, i.e. customers for a premium service. Those hybrid business models that are based on free offerings (see e.g. McGrath, 2010), however, rely on more than one value proposition and different customer groups. Second, the free offerings are often designed for a wide range of users, i.e. mass market, and are typically standardized. Differently put, the freemium business model relies mainly on "one-size-fitsall" goods or services, or as described by Baden-Fuller and Haefliger (2013), on the value produced by "one-size-fits-all" bus system. Third, the value offering is delivered digitally, i.e. via the Internet or other digital connection onto an ICT device with a specific platform, and through a network of intermediaries, e.g. internet and cloud service providers, online distributors and other various intermediaries. Fourth, the free offering to mass customers 
does not generate any revenue streams per definition, and only inflicts costs. As mentioned earlier, monetization, or value capture is achieved by going beyond the traditional buyer-supplier relationship, and moving onto hybrid business models or replacing the free offering. Thus, a freemium business model and the companies' offerings need to be further developed, adjusted and transformed over time.

While alternative revenue streams or more generic and different patterns around freemium business models have been discussed (e.g. McGrath, 2010) the role of free users for growth has only received limited attention so far. However, 'free' seems often to be the foundation for value capture opportunities and growth in the future, such as the case of many successful e-business ventures, e.g. Facebook, Google, Linkedln, and many others.

\section{Growth, network effects and 'free' users}

Assessing the role of a freemium business model for company's growth entails analysis of the relations between the processes of opportunity identification and new venture creation and its sense-making and articulation through the business model over time. While existing studies manage to give an answer to the question of how different antecedents influence growth, they largely fail to explain underlying processes. Research so far has pointed to the following criteria that enable a company to apply a freemium business model to grow and sustain: network effects and conversion rate (Pujol, 2010).

Many freemium providers run their businesses in markets with direct network effects (Pujol, 2010). In these markets, free users are of immense value as they are the foundation for network effects. As the total number of users grow the perceived utility of social network-based applications increases due to the direct network externalities (Clements, 2004). In the presence of network externalities, a product becomes more attractive as the total number of users increases (Conner, 1995) and such attractiveness often translates into a price premium (Salganik, Dodds, \& Watts, 2006). Previous research has shown the positive impact of direct network externalities on the diffusion of digital products in various markets such as Internet instant messaging service (Wang, Hsu \& Fang, 2004), peer-to-peer file sharing service (Strahilevitz, 2003), and mobile network service (Birke \& Swann, 2006).

In multiplayer online games there is evidence that certain characteristics of a user's social network are linked with their conversion (Sylvester \& Rand, 2014). Conversion is the percentage of free users that upgrade to premium users. Besides advertisement premium user fees are often a main revenue stream for ventures employing a freemium business model. In their study Sylvester and Rand (2014) point out that the number of friends with a 
premium account and the time since the last friend converted has been a strong influence on a user's own conversion. Furthermore, researchers have pointed out that strong network effects make it harder for competitors to establish themselves in the market (Eisenmann, Parker \& Van Alstyne, 2011).

With a few exceptions (Andries, Van Looy, Lecocq, \& Debackere, 2008; Cavalcante, Kesting, \& Ulhøi, 2011; Sosna, Trevinyo-Rodriguez, \& Velamuri, 2010; Vaccaro \& Cohn, 2004), most literature on business models in general and ventures employing a freemium business model have taken a static perspective, implicitly assuming them to remain stable over time. However, as Brokaw (1993) found, a large fraction of firms change the initial market offering, the network, and the value creation logic and thus their business model. Additionally, studies show that it is this change that is crucial to success and survival of new ventures (Bamford, Dean, \& McDougall, 2000; Kazanjian \& Drazin, 1990; Reynolds \& Miller, 1992). While reasons for business model adaptation are researched to a certain extent (e.g. de Reuver, Bouwman, \& Maclnnes, 2009), the process and structure of how business models transition through the initial life-cycle phases - opportunity recognition, market entry, and market exploitation - remain under-investigated (George \& Bock, 2011). Additionally, we lack an understanding of how the business model component 'free' enables growth in these periods and how it is developed to ensure growth and sustainability. Therefore, first this study looks in depth as to how a young entrepreneurial venture's business model transforms from one stage of business development to another, and second at the role of the 'free' offering in those transformations.

The three life-cycle stages of a firm are characterised as follows, the opportunity recognition stage includes opportunity identification and selection as well as opportunity development. According to Ardichvili, Cardozo and Ray (2003) this phase is especially about the careful investigation of and sensitivity to market needs as well as the entrepreneur's ability to spot suboptimal deployment of resources. Additionally, opportunity development involves entrepreneurs' creative work for example in form of innovative orchestration of resources. In the market entry phase firms define their strategy and market positioning (Gans \&Stern, 2003) as well as their place in the value chain. Start-ups still adjust their market offering in order to find a product-market fit. In the market exploitation start-ups move from exploration to exploitation. We follow Levinthal and March (1993: 105) who define exploitation as the 'use and development of things already known' exhibiting returns that are positive, proximate and predictable.

This article sets out to explore the development undergone by young entrepreneurial e-business ventures' freemium business models and its 
interplay with business growth employing an inductive approach to this currently under-researched phenomenon. As the area is vaguely researched, no specific hypotheses or propositions are suggested at this stage of the article, but they emerge as evidence and are analysed and discussed.

\section{Method}

We considered a case study appropriate as a research method since little is known about the relationship between growth and specific business model design (Eisenhardt, 1989). Therefore, we employed the multiple explanatory case study design for our investigation (Yin, 2003). Due to the purpose of the study, we adopted a purposeful sampling strategy (Patton, 2002) which permits studying the phenomenon of 'free' in detail, as well as gaining insight and in-depth understanding of the freemium business model (Eisenhardt \& Graebner, 2007). This sampling strategy was considered important to make a theoretical contribution through the study of cases in which the phenomena are best brought out or illustrated most completely (Ridder, Hoon, \& McCandless, 2009). Following this logic, we derived four cases representing Internet industry leaders within the fields of music, data storage, human resources, and event organization. We selected the cases according to the following criteria:

1) Age: A company should be more than five years old and must have launched their product and established itself in the market successfully. This will enable us to track the business model development and how 'free' impacted growth in the opportunity recognition, market entry, and market exploitation phase.

2) Online offering: To acknowledge specifics of online vs. offline offering, this study focuses only on companies that offer there products and services online.

3) Growth rate: When growth is conceived as a process there is little doubt that it is preferable to have several indicators of growth and that they need to be assessed at several different points in time (Davidsson et al., 2005). The company must have experienced a fast increase in users and employees. For employees more than 20 need to have joined within 5 years (Bosma, Jones, Autio, \& Levie, 2007 ) of the launch of the first version of the product.

4) Ownership: It is important with respect to legitimacy and resource acquisition possibilities that the companies are new ventures, not spinoffs of incumbents.

5) Pricing: In line with our research purpose, the company must offer a substantial part of their products or services to their users for free. 


\section{Profile of the case firms}

Our first case, Spotify, is a commercial music streaming service providing Digital Rights Management-protected music from various record labels like Sony, Warner Music Group and Universal. Founded in 2006, it has been launched in October 2008 by the Swedish start-up Spotify AB. Spotify is available in 35 nations with different versions of a freemium business model. By March 2013, Spotify has grown to six million paying customers globally and 24 million active users in total. Spotify has more than 800 employees and public reports value Spotify at more than US\$ 3 billion, based on an estimated US\$ 188 million raised in funding.

Our second case, Eventbrite, was founded in 2006, and is an international website that allows event organizers to plan and set up ticket sales and promote events of any size and publicize them across Facebook, Twitter and other social-networking tools directly from the site's interface. Eventbrite originally targeted the "odd job" of smaller events, but has grown strongly and now caters also for massive music shows. Eventbrite is using the so-called "long-tail" business model (Osterwalder \& Pigneur, 2010) and generates revenue by charging a $2.5 \%$ fee on the ticket price, plus US\$ 0.99 for every ticket sold. The business does not charge a fee for events that are free which is the case for most of the events posted on Eventbrite (approx. $70 \%$ of all events). Until mid-2013 Eventbrite received a total funding of US\$140 million and had 329 employees by the end of the same year. In September 2013, Eventbrite announced that they had processed US\$ 2 billion in gross ticket sales since they were founded.

Our third case, LinkedIn is a social network site service that provides a possibility to create, manage and share a professional identity online, build and engage with professional networks, access shared knowledge and insights, and find business opportunities. The company was founded in 2002. The company broke even in 2006, and since then its revenue practically doubled every year. More than $40 \%$ of revenues in 2012 came from recruiters, who paid to access profiles, communicate with users and for other services. In May 2011 LinkedIn closed its initial public offering, and in November 2011, its follow-on offering. LinkedIn was then valued at US\$ 1 billion. By 2012 LinkedIn had over 200 million individual, predominantly, free members.

Our fourth case, Box Inc. (formerly Box.net) is an online file sharing and Cloud content management service, which saves and stores the information uploaded by the customer to their website. It was founded in 2005 and secured US\$368.6 million of funding until today. Box offers three user account types: enterprise, business and personal. Depending on the type of account, Box has features such as storage, custom branding and administrative controls. There are also third party integrations with applications like Google 
apps, Gmail, NetSuite and Salesforce. Individuals can sign up and use limited amount of services for free though with some restrictions to the amount of storage space and file size.

For an overview of important key information and indicators of the four cases please see Appendix 1.

\section{Data}

To secure the rigor of our study we collected data from multiple sources (Hancock \& Algozzine, 2006) (for an overview of the data, please see table 1). Firstly, we collected various documentary evidence (Yin, 2003) such as annual reports, newspaper articles, press releases, white papers, as well as other secondary data such as presentations, publically available interviews with case company managers and textual data from social network sites such as Linkedln and Twitter. We collected the data for all the years of the company's existence until 2013. Secondly, we visited headquarters of two case companies - Box.com and Linkedln conducting on-site in-depth interviews. We have also conducted a number of in-depth interviews with key employees from the two other case companies via Skype. All interviews focused on the case companies' business model development from opportunity recognition to market exploitation as well as the purpose and the consequences of free offerings. The interviews lasted between 30 minutes and 1.5 hours. All interviews were digitally recorded and fully transcribed, and together with the rest of the data exported to NVivo 10 software for further analysis.

Table 1. Data sources

\begin{tabular}{llll}
\hline Data type & Sources & Data format & Length \\
\hline $\begin{array}{l}\text { In depth face-to- } \\
\text { face semi-struc- } \\
\text { tured interviews }\end{array}$ & $\begin{array}{l}\text { Long-term employees at } \\
\text { the executive level }\end{array}$ & $\begin{array}{l}\text { Digital sound } \\
\text { recordings and } \\
\text { transcriptions }\end{array}$ & $\begin{array}{l}6 \text { recorded interviews } \\
\text { of approx. 20,600 } \\
\text { words }\end{array}$ \\
$\begin{array}{l}\text { Internal archival } \\
\text { data }\end{array}$ & $\begin{array}{l}\text { Press releases, white } \\
\text { papers, internal reports } \\
\text { and presentations, video } \\
\text { archives, social media }\end{array}$ & $\begin{array}{l}\text { Electronic files and } \\
\text { recorded videos }\end{array}$ & $\begin{array}{l}351 \text { documents of } \\
\text { approx. 532,880 words }\end{array}$ \\
$\begin{array}{l}\text { External archival } \\
\text { data }\end{array}$ & $\begin{array}{l}\text { Newspaper articles, general } \\
\text { and scientific articles }\end{array}$ & Electronic files & $\begin{array}{l}321 \text { documents of } \\
\text { approx. 186,000 words }\end{array}$ \\
\hline
\end{tabular}

\section{Data analysis}

In order to establish the relationship between the business model configuration, including the 'free' component, and company growth the data 
were analysed in two rounds. The first round followed a three step process: data reduction, data display and conclusion drawing (Miles, Huberman, \& Saldana, 2014). It started with reducing the data to the relevant information corresponding to the business model components as they were laid down by Baden-Fuller and Haefliger (2013). Simultaneously, we were assigning each data piece a timestamp code corresponding to the calendar year and the month of the reported event, situation, or other development. We then generated data matrices for each calendar year of the company with the data pieces corresponding to the business model framework as it is laid down by Baden-Fuller and Haefliger (2013). Additionally, we reviewed our data and identified gaps and missing pieces of information for each year, and collected further documentary information to fill in the gaps.

We proceeded with data analysis by making summaries for each business model component and calendar year in the matrices and also by analysing inductively and producing open codes. The summaries were further analyzed and preliminary conclusions drawn. The matrices were consequently reduced to represent summaries and conclusions for each calendar year of operations and each business model component of our case companies. As the aim was to understand the interplay of 'free' and growth we were seeking for information on how the free offering formed over time and how its integration into the design of the business models supported growth of the case companies.

We further analysed the matrices and then grouped them for each case company in three sets, corresponding to the periods of the case companies' life-cycle stages - opportunity recognition, market entry, and market exploitation (George \& Bock, 2011) thus building representations of business model evolution. That was followed by the second round of analysis, where we were looking at various links, explanations and relationships between the business models' configurations and the growth producing a number of open codes. Those codes were consequently grouped in categories and themes, following the logic of inductive, analytic and interpretive inquiry processes (Lincoln \& Guba, 1990).

Finally, we conducted in-depth case analyses highlighting the development of business models and the role of 'free' in the individual cases through the initial life-cycle phases as well as the interplay of the freemium business model and growth of the companies. Afterwards we compared the findings of the individual cases across our four cases. We will highlight in the following the similarities which were recurrent in all four cases across the three life-cycle phases. 


\section{Findings}

All four cases present high growth entrepreneurial ventures' in term of users, customers and revenue over the three distinct stages of development - opportunity recognition, market entry, and market exploitation. Despite their success (and critiques from various sides) all companies kept on to their free market offering, most of them expanding and innovating it over the years. In this way they differentiate themselves clearly from companies that use 'free' for beta-testing or short-term advertising. The results that we present in the following shed further light on the importance of their free offering, its development and its impact on growth. For a summary of how the business models of the various companies developed please see Table 2. Table 3 provides an overview of how free users and the freemium offering influenced growth.

In the opportunity recognition stage all four case companies employed a nascent business model and focused on building up the product in line with customer requirements in order to reach a product-market fit. Nascent business models are business models without a sustainable monetization component, for finding a new sustainable business model through a series of dynamic adjustments. The companies at this early stage only focused on early adaptors and often access was restricted to this group. With this group the companies build up a very strong network of evangelists. The companies experienced that these users were willing to share their experiences with them, thus, being involved in value configuration and development of the market offering. Although Spotify and Eventbrite do not have any obvious network externalities, they made a tremendous effort to add a social network aspect that does. With the integration of social media such as Twitter and Facebook, both companies enable users to share music and events with friends.

Free users provide valuable information about emerging trends, new solutions that can be developed and implemented to improve either the free service, the premium service or both. The need to further develop the products and advance technological solutions is facilitated by attracting substantial external capital. For example, according to press releases and newspaper reports in 2006 - the second year of operations - Box counted 500,000 registered users and received $\$ 1.5$ million in A-series funding from Draper Fisher Jurvetson. Just one year later, Box raised a Series B round of \$6 million. Free users were from very early on in the company's development understood as important to acquire resources.

After creating a market offering that is highly relevant for evangelists the companies focused on volume and user growth in the market entry phase. The final version of the business model of the opportunity recognition stage 
was then scaled up. Scaling in terms of users was achieved through first, word-to-mouth marketing of existing free users and second, heavy use of web analytics to understand their free users.

With regards to the first issue, all case companies experienced that if their offering provides value to free users, then existing users would likely assist spreading of the software/application through word-to-mouth promotion. In the market entry phase this would lead to a fast growth of free users and the platform as the following quote illustrates:

"The free events and the free attendees are of huge value to our company. People are adding wonderful inventory to our platform; people who are telling their friends about us when they've had positive experience with us. So it is a wonderful way for us to build quality inventory, to reach new attendees, and also to a certain degree to expose people to the product." (interview with a representative of case \# 2)

With regards to the second issue, web analytics became of major importance for all companies as a tool to understand users and customers. The technology provided ample data on user online behaviour and preferences, and allowed the companies to adjust their value propositions to serve their customers. Having big numbers of product users, permitted the companies to figure out which features potential customers would be willing to pay for, and also to make a segmentation of different customer groups. For example, LinkedIn monitored the behaviour of its users on the online platform, and based on the observations they assigned the members to three categories of customers: relationship managers, contactors, and networkers (Piskorski, 2007). Companies in this stage clearly separated free from premium offering. The use of free offering at this stage is of a relational nature, as companies focused not only on growing user numbers, but also seriously processed information in order to identify and increase numbers of paying customers. Moreover, through the growth in users the company could build up a brand and get a lot of awareness from the media. This expansion was matched with a growth in number of employees, external finance etc.

At this stage, the case companies actively turn to additional free offerings to maintain a high degree of user and customer satisfaction. For example, according to social media and press releases, Box regularly added additional free storage to its non-paying users, and to a greater extent, to existing subscribers. In 2010 it launched a free app for iPads and iPhones based on Apple's iOS operating system. The free app connected online document repository to iOS devices and allowed subscription customers (both paying and free) to browse and preview their files online. A free subscription gave one gigabyte of storage, and as the iPad and iPhone apps were also free, some users considered it worth signing up just for the easy transfer of files 
between their mobile devices and computers. Another good example comes from Spotify. Initially, the company limited free users as to which platforms they could use and as to how many hours they could enjoy the streaming for free. In 2014 the limit was removed, and users were allowed to download and use Spotify music streaming on their mobile or tablet absolutely free of charge. This also shows that free users were not taken for granted, but value was added for them throughout to retain them.

In the market exploitation phase the companies changed their focus to performance and establishing themselves as industry leaders. They started building complementary products (in-house and in cooperation) to retain and lock-in customers. These complementary products are often offered again for free, but their offering becomes more complex and more suitable for the $\mathrm{B} 2 \mathrm{~B}$ context. Free users appear to play a significant role in the transition from a B2C to B2B as they often were the door opener towards potential B2B customers. On the one hand, satisfied users would bring the product into the company on their own:

"In many cases someone signs up for free and then, over time they like (our service) so much that they will bring it into their work life and they will say 'hey, we could you use this for our team, our projects, our company' and then it starts spreading throughout the organization." (interview with a representative of case \# 4)

On the other hand, our case companies would approach free users actively and involve them in a conversation if their offering (which the user has been using only privately so far) would also be interesting for the company they work for as the following quote shows:

"It's a great way to get into businesses. It gives us a lead, right? We of course track everything... and when we see that somebody signs up with a Coca Cola address and they start sharing with other Coca Cola users, we can see the network effect. Then suddenly we can call them up and say: 'Oh, I see you are using our product. Have you thought about upgrading to the business account?' Right? It's a great way for us to get leads. Once you get those hot leads, then you have to go and start talking to the $\mathrm{ClO}$ s and the business decision-makers. 'Cause a lot of times people who sign up online might be low level individuals, or individual contributors, and not managers. But they can still make introductions to us. So, of course, our sales team is being trained to go and work... you know." (interview with a representative of case \# 4).

Furthermore, internationalization becomes a main priority for the companies. They expand their physical presence internationally and localize the product in the market entry phase. Often companies add headquarters in other destinations to gain more local knowledge and easier access to local channels if needed. 
Table 2. Business model elements' development in the opportunity recognition, market entry, and market exploitation stage

\begin{tabular}{|c|c|c|c|}
\hline & $\begin{array}{l}\text { Opportunity } \\
\text { recognition }\end{array}$ & Market entry & Market exploitation \\
\hline $\begin{array}{l}\text { Value proposition } \\
\text { development }\end{array}$ & $\begin{array}{l}\text { Create a unique } \\
\text { value proposition } \\
\text { (i.e. different from } \\
\text { competitors) }\end{array}$ & $\begin{array}{l}\text { Adjust value } \\
\text { proposition to user } \\
\text { and customer needs }\end{array}$ & $\begin{array}{l}\text { Review value proposition; } \\
\text { launch complementary } \\
\text { offerings explore new } \\
\text { offerings for new } \\
\text { segments, e.g. B2B market }\end{array}$ \\
\hline $\begin{array}{l}\text { Customer } \\
\text { identification }\end{array}$ & $\begin{array}{l}\text { Mass market } \\
\text { consisting mainly of } \\
\text { individuals }\end{array}$ & $\begin{array}{l}\text { Mass market, } \\
\text { small and medium } \\
\text { enterprises }\end{array}$ & $\begin{array}{l}\text { Mass market, small and } \\
\text { medium enterprises, large } \\
\text { companies }\end{array}$ \\
\hline $\begin{array}{l}\text { Customer } \\
\text { engagement }\end{array}$ & $\begin{array}{l}\text { Interaction with early } \\
\text { adaptors; attraction } \\
\text { of maximum possible } \\
\text { users }\end{array}$ & $\begin{array}{l}\text { Cooperation on } \\
\text { product development, } \\
\text { increased customer } \\
\text { outreach through } \\
\text { third-party products }\end{array}$ & $\begin{array}{l}\text { Long-term agreements } \\
\text { with paying customers }\end{array}$ \\
\hline Value delivery & $\begin{array}{l}\text { Directly through own } \\
\text { channels }\end{array}$ & $\begin{array}{l}\text { Directly and through } \\
\text { own channels and } \\
\text { through popular } \\
\text { online third-party } \\
\text { applications }\end{array}$ & $\begin{array}{l}\text { Directly through own } \\
\text { channels, through } \\
\text { popular third-party online } \\
\text { applications, and through } \\
\text { bundling with digital and } \\
\text { physical products }\end{array}$ \\
\hline Monetization & $\begin{array}{l}\text { Large numbers of free } \\
\text { users (negative) }\end{array}$ & $\begin{array}{l}\text { Large numbers of } \\
\text { free users (negative), } \\
\text { revenues from } \\
\text { growing number of } \\
\text { paying customers } \\
\text { (positive) }\end{array}$ & $\begin{array}{l}\text { Large numbers of free } \\
\text { users (negative), revenues } \\
\text { from growing number } \\
\text { of paying customers and } \\
\text { large companies (positive) }\end{array}$ \\
\hline $\begin{array}{l}\text { Business model } \\
\text { components that } \\
\text { are subject to } \\
\text { change }\end{array}$ & $\begin{array}{l}\text { Focus on value } \\
\text { configuration, } \\
\text { customer } \\
\text { identification and } \\
\text { value chain linkages }\end{array}$ & $\begin{array}{l}\text { Focus on customer } \\
\text { engagement; search } \\
\text { for sustainable } \\
\text { revenue model, i.e., } \\
\text { monetization }\end{array}$ & $\begin{array}{l}\text { Optimize revenue model } \\
\text { and secure value capture. }\end{array}$ \\
\hline
\end{tabular}

Table 3. Entrepreneurial and strategic orientation in the opportunity recognition, market entry, and market exploitation stage

\begin{tabular}{|c|c|c|c|}
\hline & $\begin{array}{l}\text { Opportunity } \\
\text { recognition }\end{array}$ & Market entry & Market exploitation \\
\hline Foci & $\begin{array}{l}\text { Build product; } \\
\text { understand customer; } \\
\text { find product-market } \\
\text { fit }\end{array}$ & $\begin{array}{l}\text { Increase market } \\
\text { penetration, gain } \\
\text { market share, find } \\
\text { new (i.e. paying) } \\
\text { customer segments }\end{array}$ & $\begin{array}{l}\text { Product adaptation, } \\
\text { grow product } \\
\text { portfolio, establish } \\
\text { company as industry } \\
\text { leader, secure } \\
\text { performance, lock-in } \\
\text { customers }\end{array}$ \\
\hline Role of free offering & Attract early adaptors & $\begin{array}{l}\text { Attract as many } \\
\text { consumers as possible } \\
\text { (network effects); } \\
\text { build product/firm } \\
\text { awareness }\end{array}$ & $\begin{array}{l}\text { Attract mass market } \\
\text { consumers; retain } \\
\text { customers }\end{array}$ \\
\hline
\end{tabular}


Role of free users

Basis for trial-anderror learning and exploration

Role of paying customer Growth to-pay Growth through
Explore willingnessattracting external capital

Business model ideation and creation

Business model change (Calvacante et al. 2011; Günzel, 2011) Internationalization

Unintended organic
Basis for R\&D, legitimization of the market offering and company, important resource for further resource acquisition Gain recognition and legitimize business Growth through increasing user numbers, attracting external capital, hiring employees Business model validation
Access to paying customers (especially companies)

\section{Secure revenue} streams Growth through value extension and new customer acquisition; growth through partnerships Scaling of business model

Targeted based on organic adaptation

\section{DISCUSSION}

With this research we add to the evolutionary view in the business model literature. Scholars in this stream of business model literature focus "on the role of experimentation in the generation and change of business models" (Martins, Rindova and Greenbaum, 2015: 101). We find that the business model component 'free' plays a central role for experimentation and learning and conclude that the business model component 'free' is employed in various ways throughout the initial life-cycle stages of a new venture for reasons of trial-and-error, exploration, adjustment, legitimization and resource acquisition.

The observed variations in business model configuration also reflect the strategic objectives of the new entrepreneurial firms at different stages of growth, and can be viewed as the representation of the realised strategy (Casadesus-Masanell and Ricart, 2010). While the case companies were building up their presence in the marketplace trying to conquer a market share that would permit further growth, their business models were still in some early stage of development, as they missed the main component, i.e. monetisation (Baden-Fuller and Haefliger, 2013), to become sustainable. This approach to business model development is closely related to the discovery driven approach of strategizing and business model configuration as it is laid out by McGrath (2010). Moreover, the collected evidence suggests that there might be different stages in business model development from the early-birth to maturity, where the business model undergoes a series of major transformations. While the choice of free offering was a management decision, the consequences of that choice can be seen in the next-stage 
business model configuration, i.e. inline with the view on business models emphasised by Casadesus-Masanell and Ricart (2010).

In our cases the free business model served as a nascent business model, a business model without a sustainable monetization component, for finding a sustainable business model through a series of dynamic adjustments. A nascent business model has temporary character and is used for exploration to move from idea to practice. The nascent business model is employed in a period of intensive learning and experimentation. Experimentation refers to 1) performing practices that are new to the market e.g. collaborating with new partners, 2) exploring the willingness to pay of customers and 3) researching the possibilities to use technology to respond to market needs. Learning means 1 ) acquiring new insights into customer needs, 2) understanding how to differentiate the market offering from that of competitors, and 3 ) realizing potential for collaboration with other start-ups and stakeholders. The later is of utmost importance to overcome financial shortages.

At later stages of venture creation, the component 'free' is maintained for the purpose of market development or penetration. Here 'free' plays an important role to attract and engage as many consumers as possible and thereby take advantage of network effects. Furthermore, the companies still learn and adjust their value proposition. Especially, companies continuously adapt which parts of a product should be free and which should belong to a premium offer. These findings are in line with Sosna et al. (2010) who state that during the first years of the company initial exploration of the "best" business model takes place followed by the exploitation phase when a viable business model emerges and continuous trial and error still take place, but without changing the core of the company. In this paper we show the relevance of the component 'free' to enable the experimentation and learning that Sosna et al. (2010) point to.

In recent years, business model design has been described as a performance driver of entrepreneurial firms (Amit \& Zott, 2001). In their 2007 paper, Zott and Amit (2007) identify two critical dimensions of business model design, which they denote as "efficiency-centered" and "novelty-centered", which is similar to the strategic management thought of pursuing cost-based and differentiation strategies of incumbent firms. However, little knowledge has ever since been gained on how business models can be designed and developed over time to drive performance and growth of an entrepreneurial firm. Here this paper's underlying approach and its presented insights can contribute. Business model design for performance and growth is not an issue that can be addressed in a static manner. As pointed out in previous research (Bamford et al., 2000; Kazanjian \& Drazin, 1990; Reynolds \& Miller, 1992), business models, especially of young entrepreneurial ventures, need 
adjustment and refinement over time and thus longitudinal research studies are also needed to investigate the phenomena holistically. This research makes a first attempt using a wide range of empirical data to provide more in-depth knowledge how business models can change to be a performance driver of the company.

With this research we also responded to a call in recent entrepreneurship literature to focus rather on "how" firms develop and grow than on "how much" (Davidsson, et al., 2005; Leitch, et al., 2010; McKelvie \& Wiklund, 2010). As suggested by McKelvie and Wiklund (2010) we have made use of in-depth methods to better capture the process that leads to growth and thereby generate novel insights. One interesting finding of our study is that growth comes before profitability when successfully applying freemium business models. This is in contrast to recent findings in the growth literature that indicate that firms that grow successfully do so by first securing profitability, and then going for growth (Davidsson et al., 2005). That is why researchers have called for caution against a universal and uncritical growth ideology. As it appears, firms that grow at low profitability often end up in the undesirable state of low growth and low profits instead. Here the process of business model development might shed some more nuanced light on the phenomena. The four cases, that have been investigated in this study, are all based on strong network effects. They employed a growth-beforeprofitability strategy and became profitable in the long run. Therefore, the business model, bridging internal development and opportunity recognition in an entrepreneurial setting (George \& Bock, 2011), might be an interesting unit of analysis when studying growth as it can depict the complexity of the phenomenon growth.

\section{CONCLUSION}

With this study we contribute to this on-going dialogue of researchers and practitioners. Our findings show that the component 'free' in business models serves different purposes through the initial life-cycle stages of a young entrepreneurial venture: learning, exploration, adjustment, access, growth and legitimization. Free business models serve in the opportunity recognition stage as a nascent business model for finding a new sustainable business model through a serious of dynamic adjustments.

The free offering being initially the value produced by the "one-size-fitsall" or bus system, as described by Baden-Fuller and Haefliger (2013) brings the firm a growing pool of users, who despite the costs become a valuable strategic resource for further business model development. At a later stage, the free offering was consistently used as a customer engagement element 
of the BM, and also to promote new initiatives and maintain customer loyalty to retain the existing user and customer base. Moreover, 'free' enables new ventures to identify and segment customer groups that can potentially become paying customers. That also leads to new specifically targeted offerings, i.e. adding new customer engagement elements to the business model. Those are tailored for specific customer groups, i.e. the "taxi" service and lead to enhanced chances for monetization. Value capture is then secured by relationship, and moving onto hybrid business models or replacing the free offering with a targeted value propositions for specific groups of paying customers. In this way, the 'free' element is organically integrated in business model creation and further development until a business model becomes sustainable. At later stages, the 'free' component can be maintained for purposes of further market development or penetration.

These findings contribute to the business model literature as to the ongoing discussion about the development of business models over time and their impact on growth and performance. For the first time. we inform the literature in-depth about the many-sidedness of the component 'free' in business models and how it builds the foundation for value capture opportunities.

\section{Implications for research}

Several new research questions emerged during the analysis of the data from this multiple case study. First, we call for more research on freemium business models as it is a widely applied business model in practice but hardly understood. We have taken a first step in this paper to explore the property 'free' and how it can lead to growth. As this is a multiple case study, larger studies would be needed to confirm and elaborate our findings. Furthermore, more in-depth case studies solely focusing on free users as a resource might be interesting to conduct.

For business model researchers it might be interesting to further explore the concept of the nascent business model which we present for the first time in this paper. In addition, like Demil and Lecocq (2010) we recognize that the freemium business model approach of various companies (in our case four case companies) differs, both in the value proposed to consumers and in how transactions are organized. At the individual level of analysis, each organization's own specific business model is linked to a more generic (i.e. a more conceptual) business model. In our case the freemium business model's archetype was linked to the multi-sided platform and long-tail business model archetype (for specification see Appendix 1). The question arises if certain combinations of business model archetypes yield superior performance? 


\section{Implications for practice}

Start-up and entrepreneurial firms' development has long been an important management research theme. The topic has significant appeal to entrepreneurs, management researchers, business consultants, investors and economic development agencies. Each of these stakeholders has an interest in understanding how and why growth occurs, as well as the entrepreneurial, organizational and strategic factors that influence an entrepreneurial venture's ability to achieve growth, and the paper suggests a growth model that differs in its logic and intermediary objectives and is suitable for the digital world.

Our research, thus, yields implications for managerial e-business practice. Free users appear to be of strategic interest for companies applying successfully freemium business models. This alters the companies' approach towards treating free users as a valuable resource and learning how to perform key activities by their means. Understanding free users in this light enables the company to build up a strong network, gain legitimacy and access to further resources. However, on the other side, free users are costly as any other valuable resource. A company needs to constantly innovate constantly for its free users and update their services. Here, entrepreneurs and managers need to consider a cost-benefit balance by reflecting on the market size, network externalities and number of paying customers.

Concluding, this study offers researchers and practicing e-business entrepreneurs a deeper appreciation of the challenges of growing an entrepreneurial venture online. Creative business ideas are valuable but present only an entry ticket to the game. In the e-business world, freemium can be used strategically to grow and become successful. Entrepreneurship and management scholars have hitherto neglected the value of freemium and its strategic importance. We show how freemium can be used strategically over the span of many years to grow an entrepreneurial venture. However, we need to state that this is a long process of experimentation and learning where the companies pay ongoing for the costs of their free users which need to be treated respectfully. In addition, we show the complexity that is associated with growing a freemium e-business venture successfully. No wonder that so few survive to bring about these fantastic online market offerings that we enjoy so much every day.

\section{References}

Achtenhagen, L., Naldi, L., \& Melin, L. (2010). "Business Growth"Do practitioners and scholars really talk about the same thing? Entrepreneurship Theory and Practice, 32(2), 289-316. 
Amit, R., \& Zott, C. (2001). Value creation in e-business. Strategic Management Journal, 22(6-7), 493-520.

Anderson, C. (2009). Free: The Future of a Radical Price: Random House.

Andries, P., Van Looy, B., Lecocq, C., \& Debackere, K. (2008, May). New ventures in emerging industries: Approaches to business model adaptation. Paper presented at the 16th HTSF High Technology Small Firms Conference, Twente, Netherlands.

Ardichvili, A., Cardozo, R., \& Ray, S. (2003). A theory of entrepreneurial opportunity identification and development. Journal of Business Venturing, 18(1), 105-123.

Baden-Fuller, C., \& Haefliger, S. (2013). Business models and technological innovation. Long Range Planning, 46(6), 419-426.

Baden-Fuller, C., \& Mangematin, V. (2013). Business models: A challenging agenda. Strategic Organization, 11(4), 418-427.

Baden-Fuller, C., \& Morgan, M. S. (2010). Business models as models. Long Range Planning, 43(2-3), 156-171.

Bamford, C. E., Dean, T. J., \& McDougall, P. P. (2000). An examination of the impact of initial founding conditions and decisions upon the performance of new bank start-ups. Journal of Business Venturing, 15(3), 253-277.

Baum, J. R., Locke, E. A., \& Smith, K. G. (2001). A multidimensional model of venture growth. Academy of Management Journal, 44(2), 292-303.

Bhide, A. (2000). The Origin and Evolution of New Businesses. New York, NY: Oxford University Press.

Birke, D., \& Swann, G. P. (2006). Network Effects and the Choice of Mobile Phone Operator. Journal of Evolutionary Economics, 16(1-2), 65-84.

Bosma, N., Jones, K., Autio, E., \& Levie, J. (2007). Executive Report Global Entrepreneurship Monitor: Babson College, Babson Park, MA, US, London Business School, London, UK.

Brokaw, L. (1993). The Truth About Start-Ups. Retrieved from http://www.inc. com/magazine/19930301/3440.html.

Casadesus-Masanell, R., \& Ricart, E. J. (2010). From strategy to business models and onto tactics. Long Range Planning, 43(2-3), 195-195.

Cavalcante, S. A., Kesting, P., \& Ulhøi, J. P. (2011). Business model dynamics and innovation: (Re)establishing the missing linkages. Management Decision, 49(8), 1327-1342.

Chesbrough, H., \& Rosenbloom, R. S. (2002). The role of the business model in capturing value from innovation: Evidence from Xerox Corporation's technology spin-off companies. Industrial and corporate change, 11(3), 529-555.

Clements, M. T. (2004). Direct and Indirect Network Effects: Are They Equivalent? International Journal of Industrial Organization, 22(5), 633645.

Conner, K. R. (1995). Obtaining Strategic Advantage from Being Imitated: When Can Encouraging "Clones" Pay? Management Science, 41(2), 209225. 
Daft, R. L., \& Lewin, A. Y. (1993). Where are the theories for the "new" organizational forms? An Editorial Essay. Organization Science, 4(4), i-vi.

Davidsson, P., Achtenhagen, L., \& Naldi, L. (2005). Research on small firm growth: A Review. Queensland University of Technology. Retrieved from http://eprints.qut.edu.au/2072/

de Reuver, M., Bouwman, H., \& Maclnnes, I. (2009). Business model dynamics: A case survey. Journal of Theoretical and Applied Electronic Commerce Research, 4(1).

Demil, B., \& Lecocq, X. (2010). Business model evolution: In search of dynamic consistency. Long Range Planning, 43(2-3), 227-246.

Dunbar, R. L. M., \& Starbuck, W. H. (2006). Learning to design organizations and learning from designing them. Organization Science, 17(2), 171-178.

Eisenhardt, K. M. (1989). Building theories from case study research. Academy of Management Review, 14(4), 532-550.

Eisenmann, T., Parker, G., \& Van Alstyne, M. (2011). Platform envelopment. Strategic Management Journal, 32(12): 1270-1285.

Froberg, P. (2015). What is freemium? Retrieved from www.freemium.org.

George, G., \& Bock, A. J. (2011). The business model in practice and its implications for entrepreneurship research. Entrepreneurship Theory and Practice, 35(1), 83-111.

Günzel, F., \& Holm, A. B. (2013). One size does not fit all - understanding the front-end and back-end of business model innovation. International Journal of Innovation Management, 17(1).

Gans, J. S., \& Stern, S. (2003). The product market and the market for "ideas": commercialization strategies for technology entrepreneurs. Research Policy, 32(2), 333-350.

Google Inc. (2013). Financial tables. Retrieved from http://investor.google. com/financial/2013/tables.html

Hancock, D. R., \& Algozzine, B. (2006). Doing case study research: A practical guide for beginning researchers. New York: Teachers College Press.

Holm, A. B., Günzel, F., \& Ulhøi, J. P. (2013). Openness in innovation and business models: Lessons from the newspaper industry. International Journal of Technology Management, 61(3/4), 324-348.

Johnson, M. W., Christensen, C. M., \& Kagermann, H. (2008). Reinventing your business model. Harvard Business Review, 86(12), 50-59.

Kazanjian, R. K., \& Drazin, R. (1990). A stage-contingent model of design and growth for technology based new ventures. Journal of Business Venturing, 5(3), 137-150.

Kesting, P., \& Günzel-Jensen, F. (2015). SMEs and new ventures need business model sophistication. Business Horizon, 58(3): 285-293.

Leitch, C., Hill, F., \& Neergaard, H. (2010). Entrepreneurial and Business Growth and the Quest for a "Comprehensive Theory": Tilting at Windmills? Entrepreneurship Theory and Practice, 34(2), 249-260.

Levinthal, D. A., \& March, J. G. (1993). The Mytopia of Learning. Strategic Management Journal, 14(S2), 95-112. 
Lincoln, Y. S., \& Guba, E. G. (1990). Judging the quality of case study reports. International Journal of Qualitative Studies in Education, 3(1), 53-59.

Low, M. B., \& MacMillan, I. C. (1988). Entrepreneurship: Past research and future challenges. Journal of Management, 14(2), 139-161.

Martins, L. L., Rindova, V. P., \& Greenbaum, B. E. (2015). Unlocking the hidden value of concepts: a cognitive approach to business model innovation. Strategic Entrepreneurship Joural, 9(1), 99-117.

Massa, L., \& Tucci, C. L. (2013). Business model innovation. In M. Dodgson, D. M. Gann \& N. Phillips (Eds.), The Oxford Handbook of Innovation Management (420-441), Oxford University Press.

McGrath, R. G. (2010). Business models: A discovery driven approach. Long Range Planning, 43(2-3), 243-261.

McKelvie, A., \& Wiklund, J. (2010). Advancing firm growth research: A focus on growth mode instead of growth rate. Entrepreneurship Theory and Practice, 34(2), 261-288.

Mendelson, H. (2000). Organizational architecture and success in the information technology industry. Management Science, 46(4), 513-529.

Miles, M. B., Huberman, M. A., \& Saldana, J. (2014). Qualitative Data Analysis (3rd ed.). Thousands Oaks, CA: SAGE.

Osterwalder, A., \& Pigneur, Y. (2010). Business Model Generation. Hoboken, NJ: John Wiley \& Sons, Inc.

Piskorski, M. J. (2007). LinkedIn (A). Cambridge, MA: Harvard Business School. Pujol, N. (2010). Freemium: attributes of an emerging business model. Retrieved from http://ssrn.com/abstract=1718663.

Reynolds, P., \& Miller, B. (1992). New firm gestation: Conception, birth, and implications for research. Journal of Business Venturing, 7(5), 405-417.

Ridder, H.-G., Hoon, C., \& McCandless, A. (2009). The theoretical contribution of case study research to the field of strategy and management. Research Methodology in Strategy and Management, 5, 137-175.

Salganik, M. J., Dodds, P. S., \& Watts, D. J. (2006). Experimental Study of Inequality and Unpredictability in an Artificial Cultural Market. Science, 311(5762), 854-856.

Sosna, M., Trevinyo-Rodriguez, R. N., \& Velamuri, S. R. (2010). Business Model Innovation through Trial-and-Error Learning: The Naturehouse Case. Long Range Planning, 43(2-3), 383-407.

Strahilevitz, L. J. (2003). Charismatic Code, Social Norms, and the Emergence of Cooperation on the File-Swapping Networks. Virginia Law Review, 89(3), 505-595.

Sylvester, J., \& Rand, W. (2014, February) Keeping Up with the (Pre-Teen) Joneses: The Effect of Friendship on Freemium Conversion. Paper presented at the Winter Conference on Business Intelligence, Snowbird, Utah.

Teece, D. J. (2007). Explicating dynamic capabilities: the nature and microfoundations of (sustainable) enterprise performance. Strategic Management Journal, 28(13), 1319-1350. 
Teece, D. J. (2010). Business models, business strategy and innovation. Long Range Planning, 43(2-3), 172-194.

Vaccaro, V. L., \& Cohn, D. Y. (2004). The Evolution of Business Models and Marketing Strategies in the Music Industry. International Journal on Media Management, 6(1-2), 46-58.

Voelpel, S. C., Leibold, M., \& Tekie, E. B. (2004). The wheel of business model reinvention: how to reshape your business model to leapfrog competitors. Journal of Change Management, 4(3), 259-276.

Wang, C. C., Hsu, Y., \& Fang, W. 2004. Acceptance of Technology with Network Externalities: An Empirical Study of Internet Instant Messaging Services. Journal of Information Technology Theory and Application, 6(4),15-28.

Yin, R. K. (2003). Case study research: Design and methods. Thousand Oaks, London, New Delhi: Sage.

Zott, C., \& Amit, R. (2007). Business model design and the performance of entrepreneurial firms. Organization Science, 18(2), 181-199.

Zott, C., Amit, R., \& Massa, L. (2011). The business model: Recent developments and future research. Journal of Management, 37(4), 1019-1042.

\begin{abstract}
Abstrakt (in Polish)
W e-biznesie modele biznesowe Freemium staty się legalne. Jednak obecne badania dostarczaja znikomej wiedzy na temat sposobu w jaki oferta free i premium powinna być użyta, by w dłuższej perspektywie doprowadziła do wzrostu i sukcesu firmy. Prezentowane badanie ma na celu wypełnienie tej luki poprzez zbadanie, w jaki sposób cecha "free" została zastosowana w modelach biznesowych młodej przedsiębiorczości w poczqtkowej fazie etapów cyklu życia - rozpoznaniu możliwości, wejścia na rynek, i eksploatacji rynku. Uważamy, że różne formy modeli biznesowych Freemium sq stosowane w poczqtkowych etapach cyklu życia nowego przedsięwzięcia z powodu prób i błędów, uczenia się, poszukiwania, legitymizacji i pozyskiwania zasobów. Model biznesowy Freemium może również służyć jako powstajqcy model biznesowy, choć bez trwałego komponentu monetyzacji, może być wykorzystany w celu znalezienia trwałego modelu biznesowego poprzez serię dynamicznych zmian. Nasze ustalenia to wkład w literaturę dotyczqca modelu biznesowego na trzy sposoby: po pierwsze, nasze badania empiryczne pokazujq wielowymiarowość komponentu "free" w modelach biznesowych Freemium. Darmowi użytkownicy majq znaczenie dla budowania sieci, poszukiwania i eksploatacji oraz rozwoju z upływem czasu. Ponadto, tacy użytkownicy umożliwiajq, bezpośrednio i pośrednio, dalsze pozyskiwanie zasobów. Po drugie, podczas gdy dotychczasowa literatura prezentowała perspektywę statycznq, nasz wkład ilustruje dynamiczny proces projektu strategicznego modelu biznesowego na rzecz jego wzrostu. Wreszcie, wprowadzamy pojęcie powstajqcego modelu biznesowego, który jest nowy w literaturze.
\end{abstract}

Słowa kluczowe: model biznesowy, studium przypadku, przedsięwzięcie przedsiębiorcze, Freemium, wzrost, IT, powstajqcy model biznesowy. 


\section{Biographical notes}

Franziska Günzel-Jensen is Assistant Professor at the Department of Business Administration, Aarhus University, Denmark. She holds a PhD (2011) in Entrepreneurship from the Otto von Guericke University, Germany. Her research focuses on entrepreneurial decision-making, nascent entrepreneurship, business model development and design, and qualitative research methods. Franziska has advised start-ups with very diverse backgrounds from 2004 to today.

Anna B. Holm is Associate Professor at the Department of Business Administration, Business and Social Sciences, Aarhus University, Denmark. She has a PhD (2010) in organization and management theory from Aarhus University, and an MBA (1995) from the Bradford University School of Management, UK. Dr. Holm's research area includes business model design and strategic management. Prior to her academic career, Dr. Holm worked for over a decade as a business development consultant and in various managerial positions in industry. 


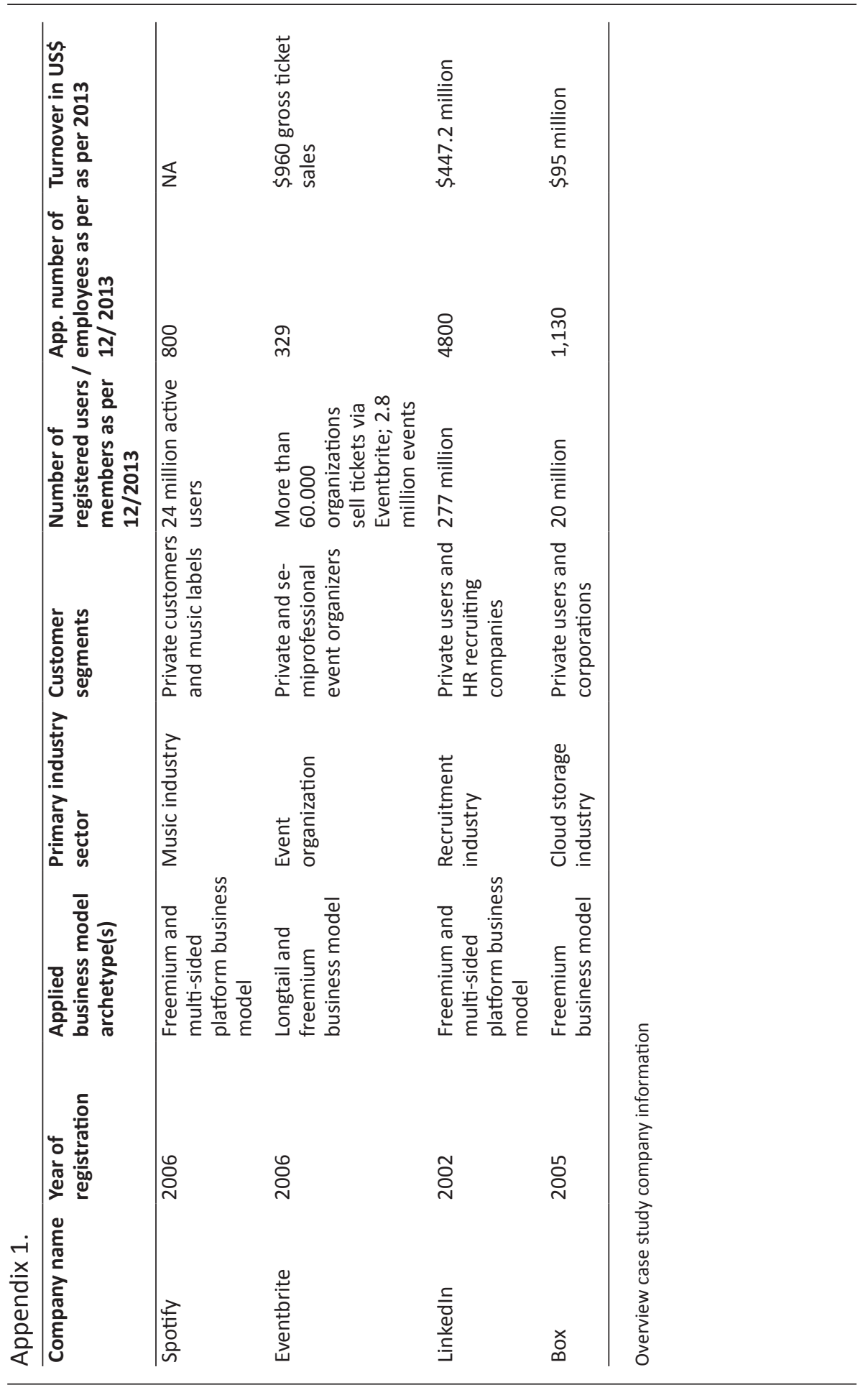


